\title{
CLIMATE CHANGE IMPACT ON RENEWABLE ENERGY RESOURCES IN THE ARAB WORLD BASED ON JACOBSON'S ROADMAP OF RENEWABLE WIND, WATER, AND SUNLIGHT (WWS) 2050
}

\author{
Waleed Abbas', Ahmed Hassan ${ }^{2}$ and Hossam Ismael ${ }^{3 *}$ \\ 'Department of geography \& GIS, faculty of Arts, Ain Shams University, Egypt. \\ ${ }^{2}$ Ministry of education, Kuwait. \\ ${ }^{3}$ Department of geography \& GIS, faculty of Arts, New Valley University, Egypt. \\ *Corresponding author: hosam.ismael@artnv.au.edu.eg \\ Received: August 6", 2020 / Accepted: May 25 ${ }^{\text {th }}, 2021$ / Published: July 15t, 2021 \\ https://DOl-10.24057/2071-9388-2020-133
}

\begin{abstract}
Most Arab countries are part of the Sunbelt where solar insolation is among the highest in the world (as high as $9.5 \mathrm{kWh} / \mathrm{m}^{2}$ per day). At the same time, Arab countries have a high-risk of climate change. Of the 19 countries that set new temperature high in 2010, five were Arab countries. Temperature in Kuwait reached $54.3^{\circ} \mathrm{C}$ in 2019. The aims of this study were fourfold: to discuss the current situation of renewable energy in the Arab countries, to analyses the regional patterns of climate change, to secure a certain amount of the future energy needs by establishing the suitability map for renewable energy exploitation, and to assess the Jacobson's «world plan»,100\% Clean and Renewable Wind, Water, and Sunlight (WWS) All-Sector Energy Roadmaps for Arab Countries according to climate change impacts 2050. To achieve these aims, the current study depended on climatic data from web-based WorldClim utility and the global climate model ECHAM5-MPIOM that downscaled by the regional climate model RegCM and CORDEX domain. A site suitability map has been developed using the Geographic Information System (GIS). We analyzed the results based on the IPCC A2 scenario for the periods 2011-2040 and 2041-2070. We found that transforming Arab countries to a 100\% WWS system as suggested by Jacobson et al. (2016) will reduce the end-user demand in 2050 by about 32\%. This difference can be attributed to the conversion of fossil fuel combustions to a more efficient sustainable renewable energy.
\end{abstract}

KEYWORDS: Sustainable Development; Renewable energy; Climate change impacts; suitability map

CITATION: Waleed Abbas, Ahmed Hassan and Hossam Ismael (2021). Climate Change Impact On Renewable Energy Resources In The Arab World Based On Jacobson's Roadmap Of Renewable Wind, Water, And Sunlight (Wws) 2050. Geography, Environment, Sustainability, Vol.14, No 2, p. 92-104 https://DOI-10.24057/2071-9388-2020-133

Conflict of interests: The authors reported no potential conflict of interest.

\section{INTRODUCTION}

The Arab countries are expected to be strongly affected by climate change, enhancing the already hot and dry climatic conditions. Furthermore, the region of limited water resources, renewable energy, and high population growth like the Arab world; a recent climate change may increase the frequency and severity of climate extremes related to the future of renewable energy (Sanchez et al. 2004; Giorgi and Lionello 2008; Önol and Semazzi 2009; Lelieveld et al. 2012; Almazroui 2013: Önol et al. 2014; Ozturk et al. 2015; Seneviratne et al. 2016).

Economically, The Arab world is one of the most extreme uneven regions in the world. The yearly Gross Domestic Product (GDP) per capita in the oil-rich Arab countries is the highest (more than US\$20,000 in the Arab Gulf countries), while it is very low (only US\$1400) in countries like Morocco and Yemen (World Bank 2016). In consequence, adaptive capacity and vulnerability to climate change hazards vary tremendously within the region (Katharina et al. 2017).
Inherently, the Arab countries have been endowed with plentiful natural energy resources wealth. The region holds about half of oil reserves and a quarter of natural gas reserves in the world. It controls almost a third of oil production and $14 \%$ of natural gas production. When renewable energy resources and climate change are considered in the same context, the analysis usually focuses on the impacts that renewables might have on mitigation of or adaptation to climate change, with the aim to reduce emissions of greenhouse gases (GHGs) list (World Bank 2016\& 2017).

Climatic variability over the next century is projected to increase, and the Arab countries may experience unprecedented weather extremes (World Bank 2016, 2017). In this connection, climate models are the only tools that enable understanding of how climate will change in the future. However, model predictions are only approximations about the future state of the climate system (Pasicko et al. 2012). The integration between global climate models (GCMs) and regional climate models (RCMs) is necessary to make climate predictions more reliable and applicable in the current study. 


\section{Previous studies}

A synthesis of the literature on climate change impacts of renewable energy show that the Arab countries region is highly affected by present and future climate change, and the region emerges as one of the hot spots for worsening extreme heat, fossil fuels into force under climate change. as a result, this has a great impact on the future of energy resources and drives the dependence on renewable energy resources available in the Arab world (Evans 2009, 2010).

Önol and Semazzi (2009) concluded that increasing concentrations of carbon dioxide in the region will exacerbate the crisis. While Lelieveld et al (2012) clarified that the region's commitment to long-term contracts to export oil and natural gas complicates leaves these countries vulnerable to the risks of climate change.

Almazroui $(2013,2019)$ concluded the necessity of getting used to climate models to predict future climate changes, with reference to the necessity of relying on climate models domain that were specially created for the countries of MENA region. Önol et al (2014) and Ozturk et al (2015) agreed on the importance of using renewable energy resources available in the countries of the region in order to avoid the repercussions of climate change impacts.

In the Arab countries, previous studies of climatic variability have focused mainly on the analysis of air temperature (El Kenawy et al. 2009; Almazouri et al. 2012) and precipitation (Nazemosadat \& Cordery 2000; Raziei et al. 2012; El Kenawy et al. 2014; Deng et al. 2015). The spatiotemporal variability of climate has been described as being driven by the atmospheric-oceanic circulation in many areas across the Middle East and North Africa (MENA) region (Nazemosadat \& Cordery 2000; Rahimzadeh et al. 20l09; Raziei et al. 2013; El Kenawy et al. 2010 \& 2014). This is of great importance when considering that the climate of the Arab region is transitional, with both midlatitude and subtropical configurations influencing the region. More attention is required to assess climate variability impacts within the Arab countries, for example on renewable energy prospects.

Overall, the motivation behind the topic of this research relies on the following three observations: Firstly, Arab countries currently are doing very poorly from a renewable energy perspective. Secondly, they have all the necessary environmental factors to have the potential to have a robust renewable energy sector. Lastly, Arab countries can greatly benefit from making the transition to relying on renewable energy. This research relied on Jacobson's plan for Arab countries in the World Plan proposal-Jacobson et al. (2016) and it has been proved that the roadmap can be doable.

\section{STUDY AREA}

The Arab countries consist of 22 states in Africa and Asia, cover a vast area of 14 million $\mathrm{Km}^{2}$, geographically, The Arab world extends from the tip-east in the Arabian Gulf to the Atlantic Ocean in the tip-west, and from the mountains of Syria and Lebanon until the tropical plateau of Somalia.

The Arab countries mainly have a transversal extent, where it roughly extends 77 Longitude, excluding distant detached Comoros. Given the world geodetic coordinate system 1984 (WGS-84), the Arab land spreads between longitudes $17^{\circ} 06^{\prime} 7.5^{\prime \prime} \mathrm{W}$ - 59 $50^{\prime} 52.4^{\prime \prime} \mathrm{E}$, and between latitudes $12^{\circ} 22^{\prime} 59.4^{\prime \prime} \mathrm{S}$ - 37 $23^{\circ} 1.0^{\prime \prime} \mathrm{E}$. The Arab lands are mostly ruled by hot arid (BWh) and semi-arid (BSh) climates in Koppen classification (Kottek M. et al. 2006). So, it forms the largest desert realm in the world, The warm climate with hot summers (CSa) dominates minor territories in Northwest Africa and northern fringes of Iraq, Syria and Lebanon. Only the Comoros characterized by an equatorial climate of fully humid (Af) and monsoonal (Am) (Figure 1). In the current research, data and analysis are presented in three sub-regions as defined in the Arab Human Development Reports (2010, 2014\& 2018): (1). The Middle East and North Africa (MENA), namely, Mauritania, Morocco, Algeria, Tunisia, Libya, Egypt, Palestinian, Jordan, Lebanon, Iraq, Syria, and Yemen (2) The Gulf Cooperation Council (GCC), including Saudi Arabia, the United Arab Emirates, Kuwait, Oman, Bahrain, and Qatar, (3) the sub-Saharan countries, namely, Sudan, Somalia, Djibouti, and Comoros. These sub-regions are strongly linked to geographic connectivity, climatic zoning, socio-economic aspects, natural resources, vulnerability patterns to climate change, and development status.

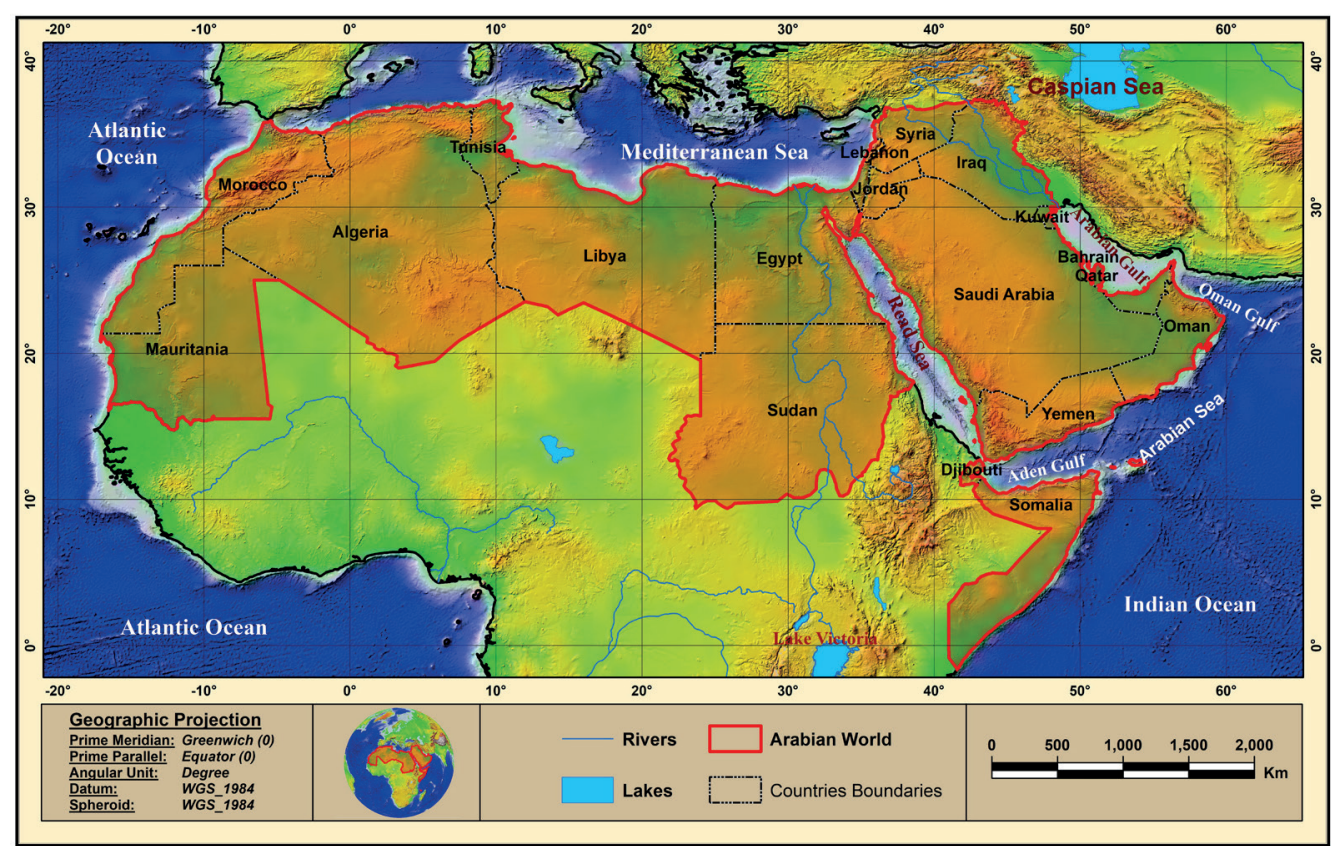

Fig. 1. The geographical location of the Arab countries 


\section{The main questions of this study were:}

- Does the Arab countries in urgent need to use renewable energy sources to mitigate the impacts of climate change?

- Does Jacobson's plan (WWS) 2050 provide Arab countries with the ideal opportunity to replace fossil fuels with renewable energy available in all Arab countries?

\section{DATA AND METHODOLOGY}

In order to answer the research questions and to assess climate change impacts on renewable energy resources in the Arab countries several data references are analyzed in the data and methodology section:

1) Tracking SDG 7: Energy Progress Report 2019, Arab Region .

2) Climatic data from WorldClim_Global Climate Data

3) Regional Climate Model (RegCM).

4) Ensemble results of CMIP5 model for two Representative Concentration Pathways (RCPS), RCP2.6 and RCP8.5, adopted by the IPCC for its fifth Assessment Report (IPCC 2013).

5) Road map of 100\% Wind, Water and Sunlight (WWS).

These sources include an updated statistical data from the energy progress report 2019 and a road map of (WWS). Also, the methodology depended on data extracted from satellite images, and climate data extracted from climate models such as; RegCM and CMIP5. The methodology and tools used in the current study are most suitable for answering our research questions because it achieved integration between all aspects of the data on which the research is based.

\section{RESULT AND DISCUSSION}

The current situation of renewable energy in the Arab countries

Only 18\% of the Arab region's renewable energy consumption is accounted for by electricity generation. Egypt, Morocco, and Sudan are high consumers of renewable energy for electricity generation in 2016, together they account for over $80 \%$ of the Arab world region are total. Table 1 illustrates that with around $13 \%$ of total renewable energy consumption, hydropower remains the most important renewable energy source in the Arab region after solid biofuel.

Solar radiation is the most abundant and widely accessible in the desert, but the least tapped form of energy in Arab countries. The world's hot deserts cover around 36 Million km² (UNEP 2012) of the earth's land surface with about 14 Million $\mathrm{km}^{2}$ in the Arab region, around 39\% of the global available hot desert. The solar radiation falling on the Arab desert area is estimated at 88,219TWh per day (assuming annual irradiation of $2300 \mathrm{kWh}$ per $\mathrm{m}^{2}$ per year) which is a vast amount.

In addition, solar-powered mini-grids have gained increased traction in a number of different settings, from Egypt's comparably large Masdar Siwa Project (2015) and benban solar park in Aswan (2017), and mini-grids on islands, as in the United Arab Emirates islands of Al Hayl and Al Jarnain (both since 2015) (International Energy Agency 2018).

Interestingly, while Arab countries are behind on its renewable energy production, with less than $7 \%$ of its energy produced by renewable (solar and wind) energy, Arab countries are actually ranked first in the world in solar water heating collector capacity per capita. This further illustrates Arab countries' renewable energy resources availability and potential (Figure 2 and 3).

Table 1. Renewable energy consumption in the Arabian countries (World Bank 2014

\begin{tabular}{|c|c|c|c|c|c|}
\hline Country & Solar & Wind & Hydro & Total (TJ) & $\%$ of Total Consumption \\
\hline Morocco & 1889 & 6942 & 5906 & 69683 & 2 \\
\hline Mauritania & 0 & 0 & 0 & 13103 & 33 \\
\hline Algeria & 0 & 0 & 691 & 902 & 0 \\
\hline Tunisia & 758 & 1458 & 161 & 40093 & 12 \\
\hline Libya & 0 & 0 & 6332 & 6332 & 2 \\
\hline Egypt & 0 & 4040 & 42950 & 11950 & 6 \\
\hline Sudan & 1015 & 6 & 174 & 6747 & 3 \\
\hline Yemen & 0 & 0 & 0 & 2372 & 1 \\
\hline Oman & 0 & 0 & 0 & 0 & 0 \\
\hline UAE & 937 & 0 & 0 & 3309 & 0 \\
\hline Qatar & 0 & 0 & 0 & 0 & 0 \\
\hline Bahrain & 0 & 0 & 0 & 0 & 0 \\
\hline Kuwait & 0 & 0 & 0 & 0 & 0 \\
\hline Iraq & 6368 & 0 & 6851 & 7894 & 3 \\
\hline KSA & 5 & 0 & 0 & 285 & 0 \\
\hline Palestine & 0 & 0 & 0 & 0 & 0 \\
\hline Jordan & 1015 & 6 & 174 & 6747 & 3 \\
\hline Lebanon & 0 & 0 & 627 & 8091 & 3 \\
\hline Syrian & 2650 & 0 & 7832 & 6770 & 11 \\
\hline
\end{tabular}


On the other hand, the solar power consumption increased markedly from very low initial rates: up 55\% across the region during the 2000s and 20\% over the period 2012-2016, especially in the GCC economies. GCC members Saudi Arabia and the United Arab Emirates have set consecutive world low-price records for utility-scale solar PV and CSP in 2016 and 2017, making solar PV costcompetitive with every other fuel on the market. Now, wind park stations in Aswan (Egypt), Morocco, and Jordan have been manufacturing extremely competitive electricity. Increased use of distributed generation, for use by both off and on-grid market segments, adds significantly to deployment in recent years.

The wind is another resource available for Arab countries to generate clean energy. Research to date suggests that it be unlikely that multi-year annual mean wind speeds will change by more than a maximum of $\pm 25 \%$ over most of the Arab countries during the present century, while research covering North Africa and the Middle East suggest that multi-year annual mean wind power densities will likely remain within $\pm 50 \%$ of current values (Figure 4).

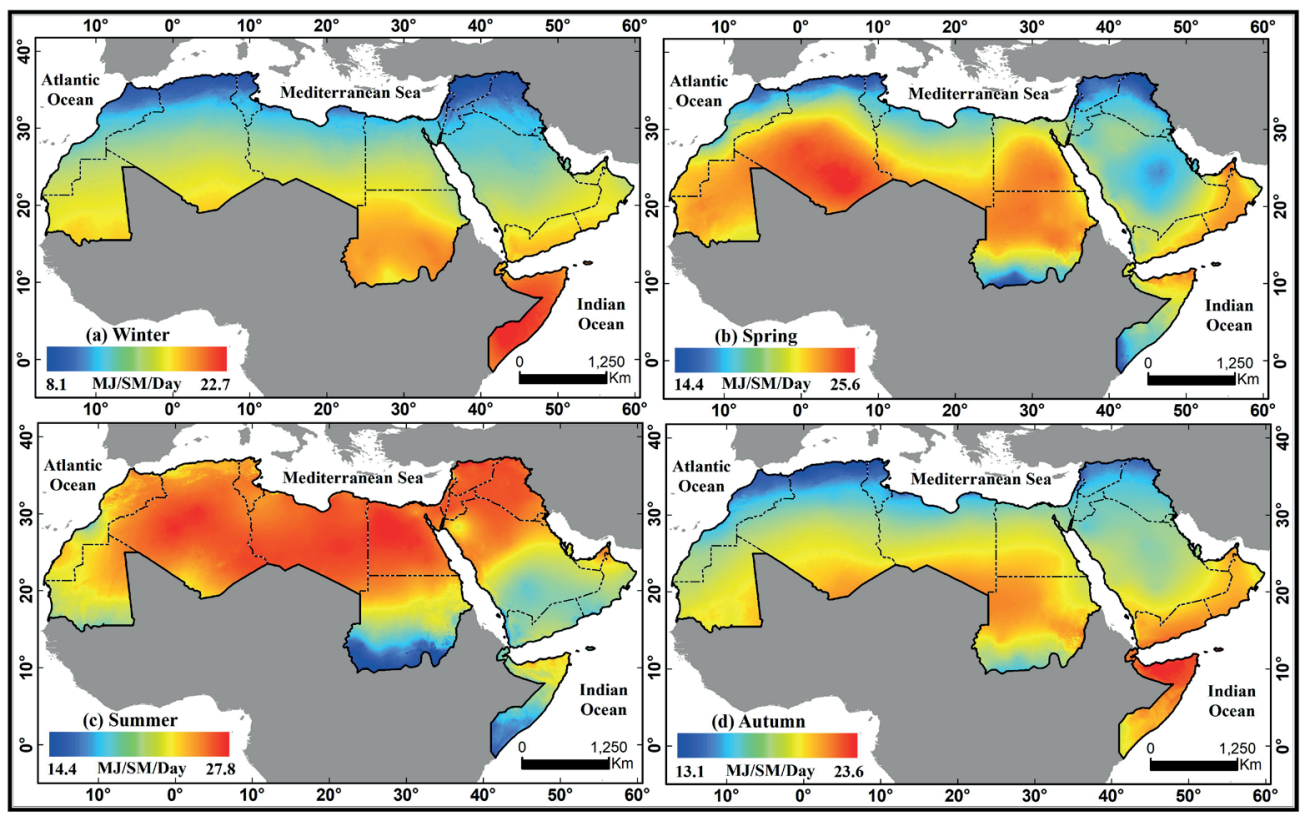

Fig. 2. Seasonal solar radiation variations in the Arab countries
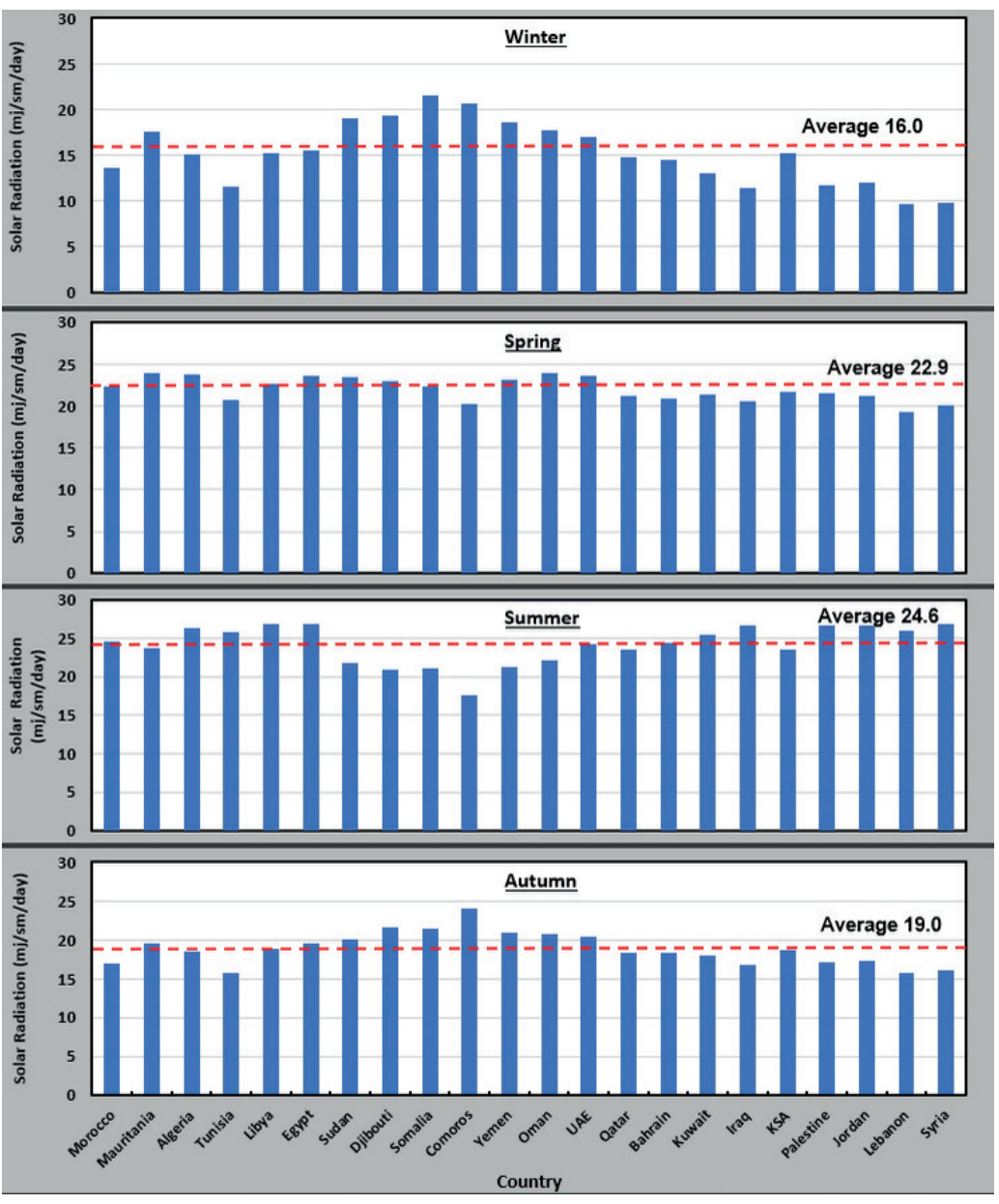

Fig. 3. Seasonal averages of insolation $\left(\mathrm{mj} \mathrm{m}^{-2} \mathrm{day}^{-1}\right)$ in the Arab countries 
To illustrate this further, wind energy is considered local, in the sense that it is available in locations where the wind speed structure has specific characteristics. It is located in main sites in the Arab world that contain (Gulf of Aqaba) in Jordan, Tunisia, and Algeria (the Mediterranean coastal plain), Sudan (the Red Sea coastline), Oman (Indian Ocean coastline), Egypt (the Red Sea coastline and the Gulf of Suez Coast), Morocco and Mauritania (the Atlantic coastline), Yemen, and some locations in the Arabian Gulf Coast (Figure 4).

Egypt, Morocco, and Sudan together account for over two-thirds of the Arab region's renewable energy consumption (UN ESCWA, 2016d). Wind energy in the Arab region has reached $2400 \mathrm{MW}$ in 2016. Installed capacities are concentrated in Egypt, Morocco, and
Tunisia. The power of renewable energy generated from wind power plants represents around $0.35 \%$ of the total electricity generated in the Arab countries (ibid, 2016d).

(Figure 5) indicates that the annual wind speed at 100 meters above ground level (AGL) in Arab countries area is about $18 \mathrm{~m} / \mathrm{s}$ and the annual capacity factor at that height, assuming $123 \mathrm{MW}$ turbines with 126-meter rotor diameter, is about 0.3. When compared to other countries, Arab countries annual wind speeds and capacities are very high. Arab countries have the highest annual wind speeds and capacities when compared to other locations; the region has in most locations high enough wind speeds to generate electricity using wind energy.

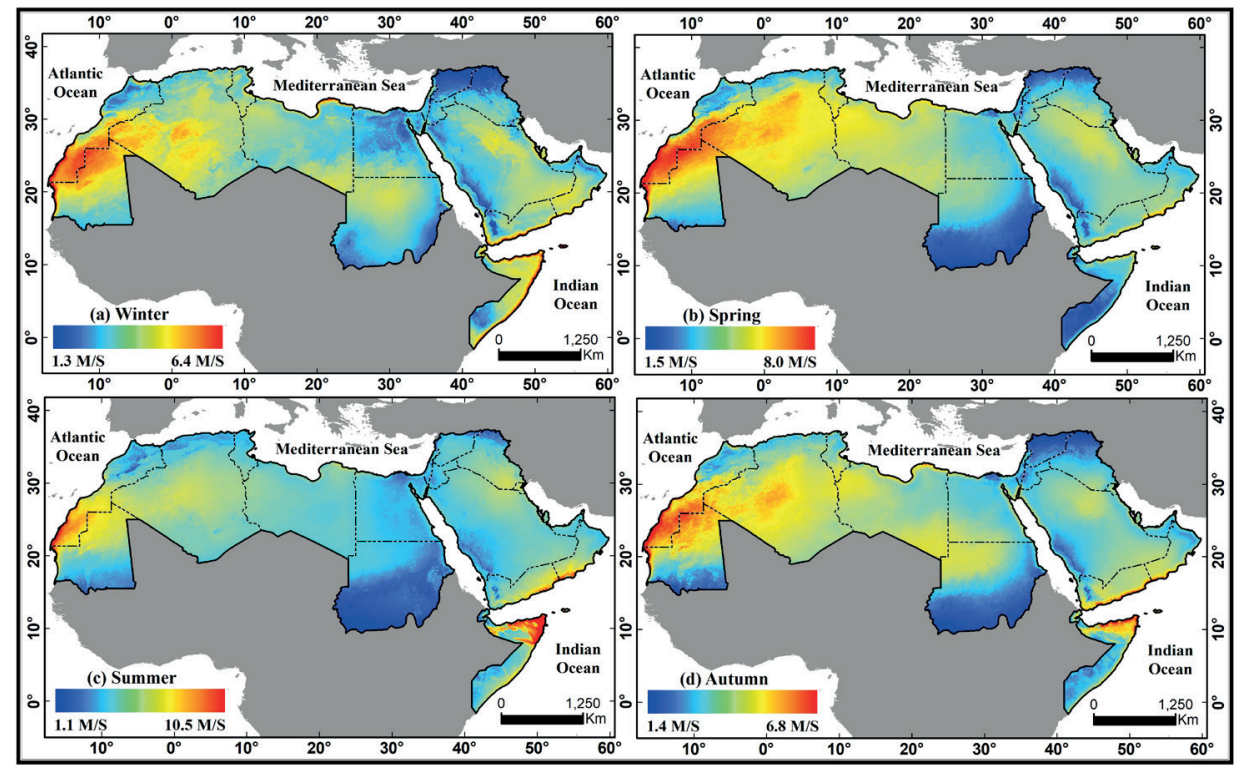

Fig. 4. Seasonal wind speed variations in the Arab countries

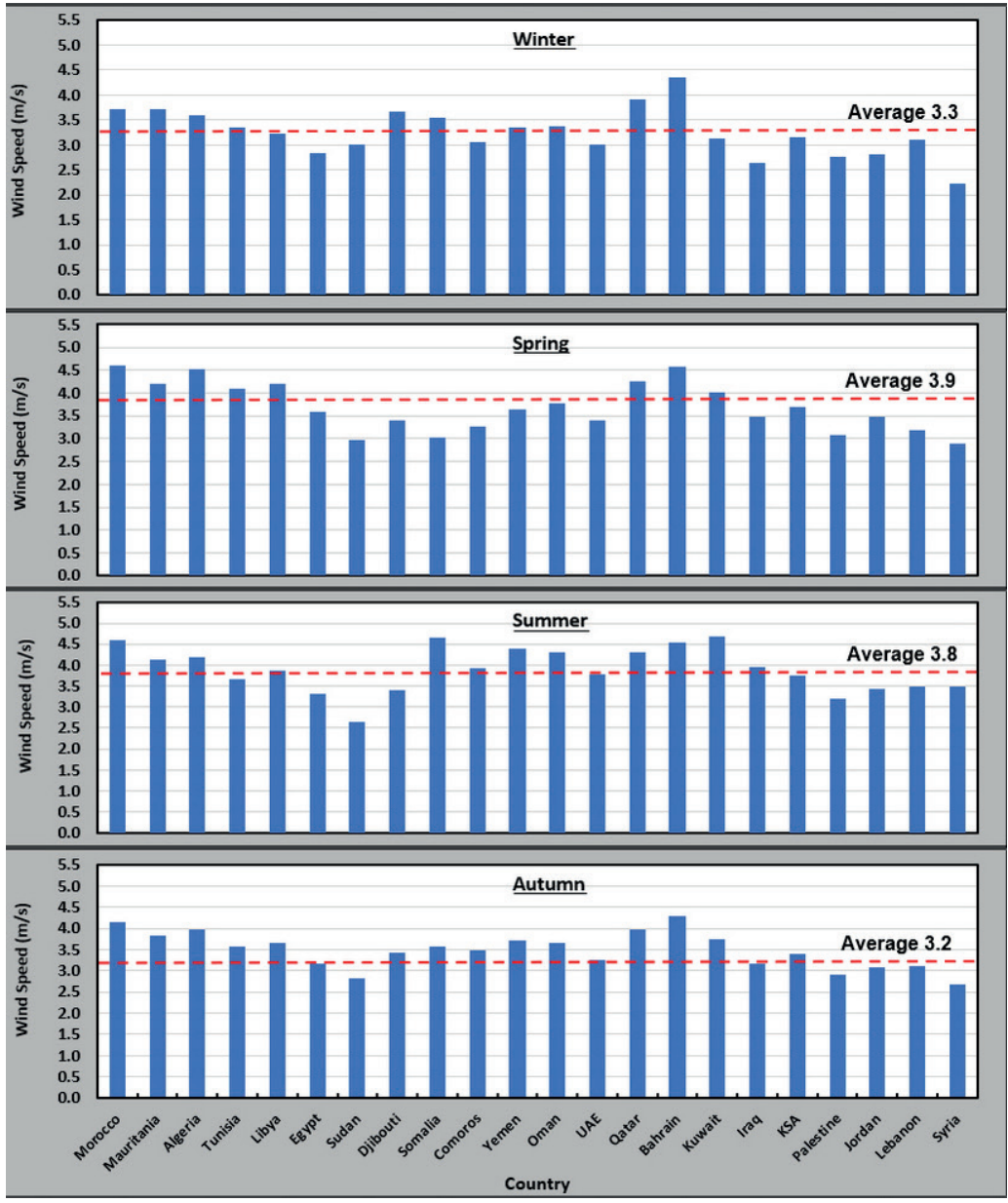

Fig. 5. Seasonal averages of the wind speed in the Arab countries ( $\left.\mathrm{ms}^{-1}\right)$ 
In sub-regional terms, renewable energy consumption is screwed in the Arab LDCs, followed by Arab countries in North Africa, with smaller quantities consumed in the Arab countries in Mashreq and almost none in the GCC economies where, despite the recent great value of solar power, renewable energies continue to account for relatively small amounts of the region's power mix (Figure 6).

A few Arab countries account for practically all the Arab region's newly used renewables-powered electricitygeneration capability. The capacity addenda in renewable energy in the Arab world from the period 2012-2015 came from Egypt (with some $700 \mathrm{MW}$ new capacities installed from 2012 to 2015). Morocco (with some $547 \mathrm{MW}$ new capacity installed during 2013 to 2014) and the UAE (113 MW new generation capacity primarily from CSP) (Table 4)

In the coming decade, both countries aim to significantly increase their renewable energy-generation capacity further: Egypt to a total of $3.200 \mathrm{MW}$, Morocco to a total of 2,000 MW installed wind and 2,000 MW solar capacity by 2022 (around 42\% of total generation capacity), to be doubled by 2030 (to account for 52\% of total generation capacity); and Dubai to 5,000 MW, or 25\% of electricity generation by 2030 in the UAE.

It can also be noticed that other countries in the region have even considerable renewable energy plans, with the elevated capacity targets currently in Saudi Arabia, aiming for 9,500 MW renewable energy by 2030; Egypt with total capacity targets of 12,500 MW (wind and solar power), or $25 \%$ of total electricity by 2022 (World Bank 2017a).

It could be observed, both wind and solar power grew significantly over the tracking period 2012-2016. New regional wind-power-generation capacity increased by around $670 \mathrm{MW}$ in 2013 and 2014, driven primarily by large-scale projects in Morocco (542 MW over a period of two years) and to a lesser extent Egypt (60 MW) and Tunisia (60 MW). Moreover, between 2012 and 2014, the Arab region combined added some $50 \mathrm{MW}$ of solar PV and over 100 MW of CSP capacities, with significantly more capacity additions since 2015 (Figure 6).
Regional Patterns of Climate Change

Temperatures and Heat Extremes

(Figure 7) illustrates a multi-model mean temperature anomaly for RCP2.6 and RCP8.5 by the Potsdam Institute for Climate change Impact Research and Climate Analytics, 2014, for the months of June-July-August for the Arab countries. The results detect that warming of about $0.2^{\circ}$ per decade has been spotted in the region from 1961 to 1990, and an even faster rate since then, which is a match with an increase in frequency in temperature extremes. Climatically, the strongest warming is projected to take place close to the Mediterranean coastal plain. The impacts not only in the coastline areas, but also in the inland of Algeria, Libya, and large parts of Egypt, warming by $3{ }^{\circ} \mathrm{C}$ in a $2{ }^{\circ} \mathrm{C}$ world scenario is predicted by 2100 . In a $4{ }^{\circ} \mathrm{C}$ world scenario, the mean summer air temperatures are forecasted to be up to $8{ }^{\circ} \mathrm{C}$ warmer in abundant areas of Algeria, KSA, and Iraq by 2100. By the end of the century, in a $2{ }^{\circ} \mathrm{C}$ world scenario, unusual heat extreme waves in temperatures will occur in about $33 \%$ of summer months almost everywhere in the Arab countries.

This means that on average one of the summer months each year will override temperatures warmer than four standard deviations beyond the baseline average. Unusual heat extreme waves, however, will reside preponderantly in a $2{ }^{\circ} \mathrm{C}$ world, unless in some isolated coastal regions overall the Mediterranean coasts of Tunisia, Egypt, Yemen, Djibouti, and Oman. Here these events are projected to be relatively rare in a $2{ }^{\circ} \mathrm{C}$ world scenario but are notwithstanding expected to occur in 5-10 percent of summer months.

Whereas the increase in the frequency of heat extremes is expected to level off by mid-century in a $2{ }^{\circ} \mathrm{C}$ world, in a $4{ }^{\circ} \mathrm{C}$ world scenario it will continue increasing to the end of the century. In a $4{ }^{\circ} \mathrm{C}$ world scenario, $80 \%$ of summer months are projected to be hotter than five degrees (unprecedented heat extremes) by 2100, and about 65\% are projected to be hotter than five degrees during the 2071-2099 period.

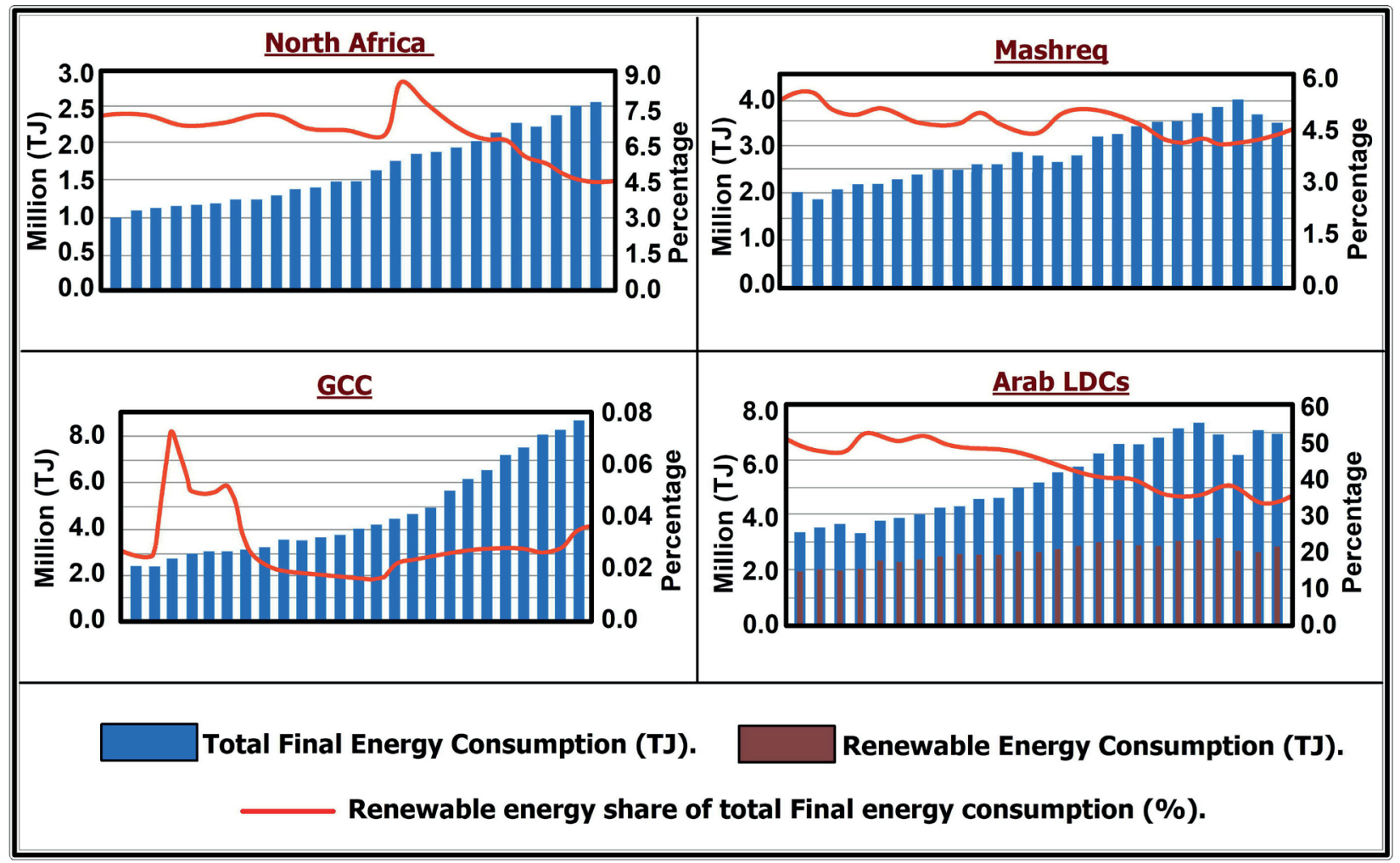

Fig. 6. World Bank determination of renewable energy share in energy consumption 2017 in the Arab subregion 

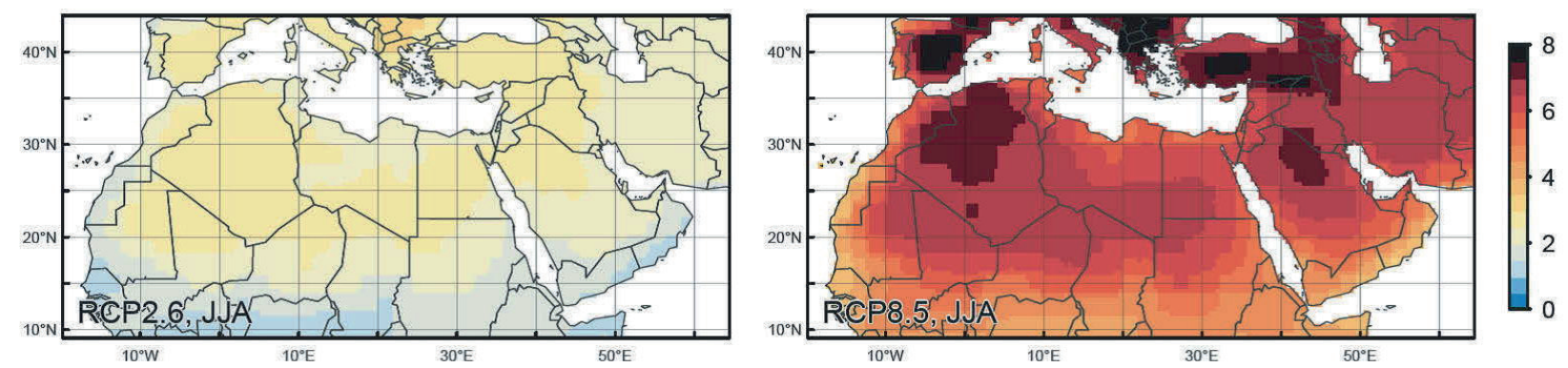

Fig. 7. Deviations from the mean temperature for the summer months according to models RCP2.6 and RCP8.5 (After Word Bank 2014)

\section{Projected Temperature Changes}

The projected increase in temperatures during the northern summer (June, July, and August) over the Arab countries is shown in Figure 9 for both the $2{ }^{\circ} \mathrm{C}$ and $4{ }^{\circ} \mathrm{C}$ world scenario. The multi-model means warming by 2100 is about $2.5^{\circ} \mathrm{C}$ in a $2{ }^{\circ} \mathrm{C}$ world, and about $7.5^{\circ} \mathrm{C}$ in a $4{ }^{\circ} \mathrm{C}$ world, which is substantially more than the global mean land warming. Under the low-emission scenario (i.e., a $2{ }^{\circ} \mathrm{C}$ world), summer temperatures in the Arab countries peak by 2040 at about $2.5^{\circ} \mathrm{C}$ above the $1951-$ 1981 baseline and remain at this level until the end of the century. In a $4{ }^{\circ} \mathrm{C}$ world scenario, the warming continues almost linearly beyond 2040 , reaching about $7.5^{\circ} \mathrm{C}$ above the 1951-1981 baseline by 2100 (Figure 8).

Climatically, the strongest warming is projected to take venue close to the Mediterranean coastal plain. Also, inland in Algeria, Libya, Tunisia, and large parts of Egypt, regions warm by $3{ }^{\circ} \mathrm{C}$ in a $2{ }^{\circ} \mathrm{C}$ world. In a $4{ }^{\circ} \mathrm{C}$ world, mean summer temperatures in 2071-2099 are expected to be up to $8{ }^{\circ} \mathrm{C}$ warmer in parts of Algeria and $6{ }^{\circ} \mathrm{C}, 7^{\circ} \mathrm{C}$ warmer in Egypt and Libya respectively. Warming over the Arabian Gulf region (i.e., below about $29^{\circ} 47 \mathrm{~N}$ in Figure 9$)$ is more moderate $\left(3^{\circ} \mathrm{C}\right.$ in a $2{ }^{\circ} \mathrm{C}$ world and $6{ }^{\circ} \mathrm{C}$ in a $4{ }^{\circ} \mathrm{C}$ world), which is likely related to an increase in precipitation.

In a $4{ }^{\circ} \mathrm{C}$ world, the prospect density functions of monthly temperatures (correlating with the year-to-year variability of monthly temperatures) shift by six standard deviations toward warmer conditions across all regions in the Arab world, from the Sahara to the Arabian Peninsula to the eastern Mediterranean coast. Such a large move beholds that summer temperature will move to a new climatic regime by the end of the 21 st century. Such a dramatic change would be avoided in a $2{ }^{\circ} \mathrm{C}$ world; even then, however, a substantial shift is expected (i.e., by about 2-4 standard deviations).
By using five GCMs indicate we find that by the end of the century, in a $2{ }^{\circ} \mathrm{C}$ world scenario, 3 unusual heat extremes will occur in about thirty-five percent of summer months almost everywhere in the Arab countries' region (Figure 9, top). This reveals that on average one of the summer months June, July, and August each year will be an unusually hot month. Five unprecedented heat extremes (Figure 9, bottom) happen much less frequently with a return period of several thousand years. 5-peak heat extremes, however, will remain broadly missing in a $2{ }^{\circ} \mathrm{C}$ world scenario, predictable for in some secluded coastal regions including the Mediterranean coasts of Egypt, Libya, and in Yemen, Djibouti and Oman (Figure 8, lower right panel). In a $4{ }^{\circ} \mathrm{C}$ world scenario, about $65 \%$ of summer months are predicted to be distributing as 5-peak heat extremes by 2071-2099 in the Arab countries. Whereas the increase in the frequency of heat extremes is predictable to standard off by mid-century with $2{ }^{\circ} \mathrm{C}$ global warming, with $4{ }^{\circ} \mathrm{C}$ global warming it will continue increasing to the end of the century.

\section{CMIP5 model results}

J. Lelieveld et al. (2016) applied results from an ensemble of 26 models that have been interpolated to a common spatial resolution of 2.5 degrees, about $280 \mathrm{~km}$ at the $0^{\circ}$ latitude (Equator). Evaluate the CMIP5 model results for the reference period, based on observations compiled in the gridded datasets of the Climate Research Unit (CRU, version 3.22), and test the level of consistency of the climate model projections we performed robustness calculations as proposed in (Figure 9). The figure presents the projected changes in near-surface temperature, for the mid- and end-century periods and the RCP 4.5 and 8.5 scenarios.

(Figure 9) shows that the level of robustness is high, especially for the summer warming, and is highest for

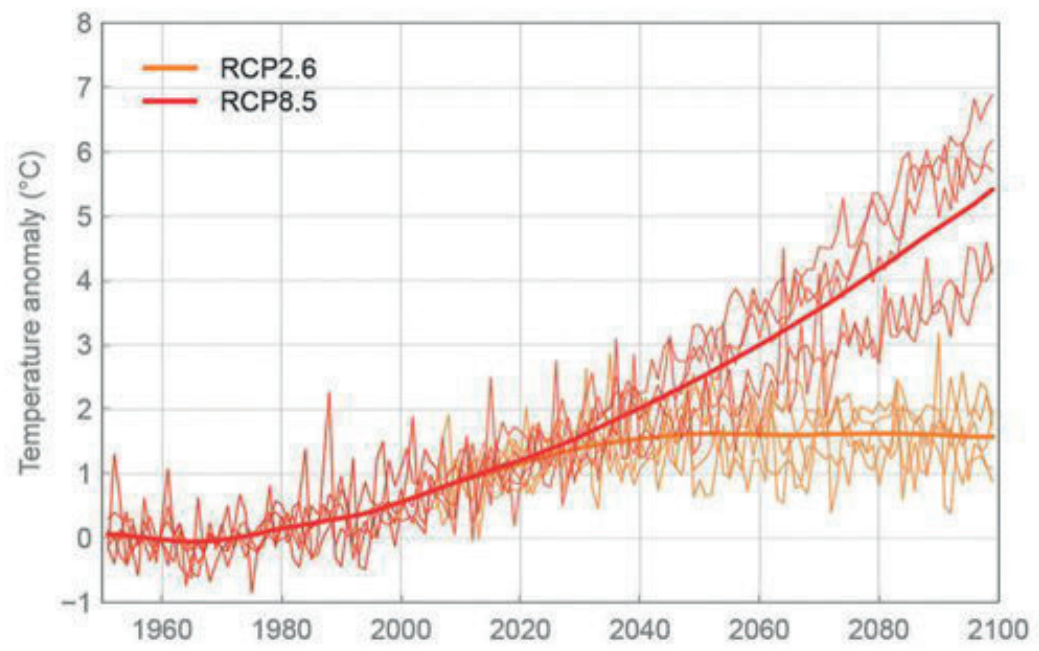

Fig. 8. Interannual temperature projections for MENA land area compared to the baseline (1951-1980) 

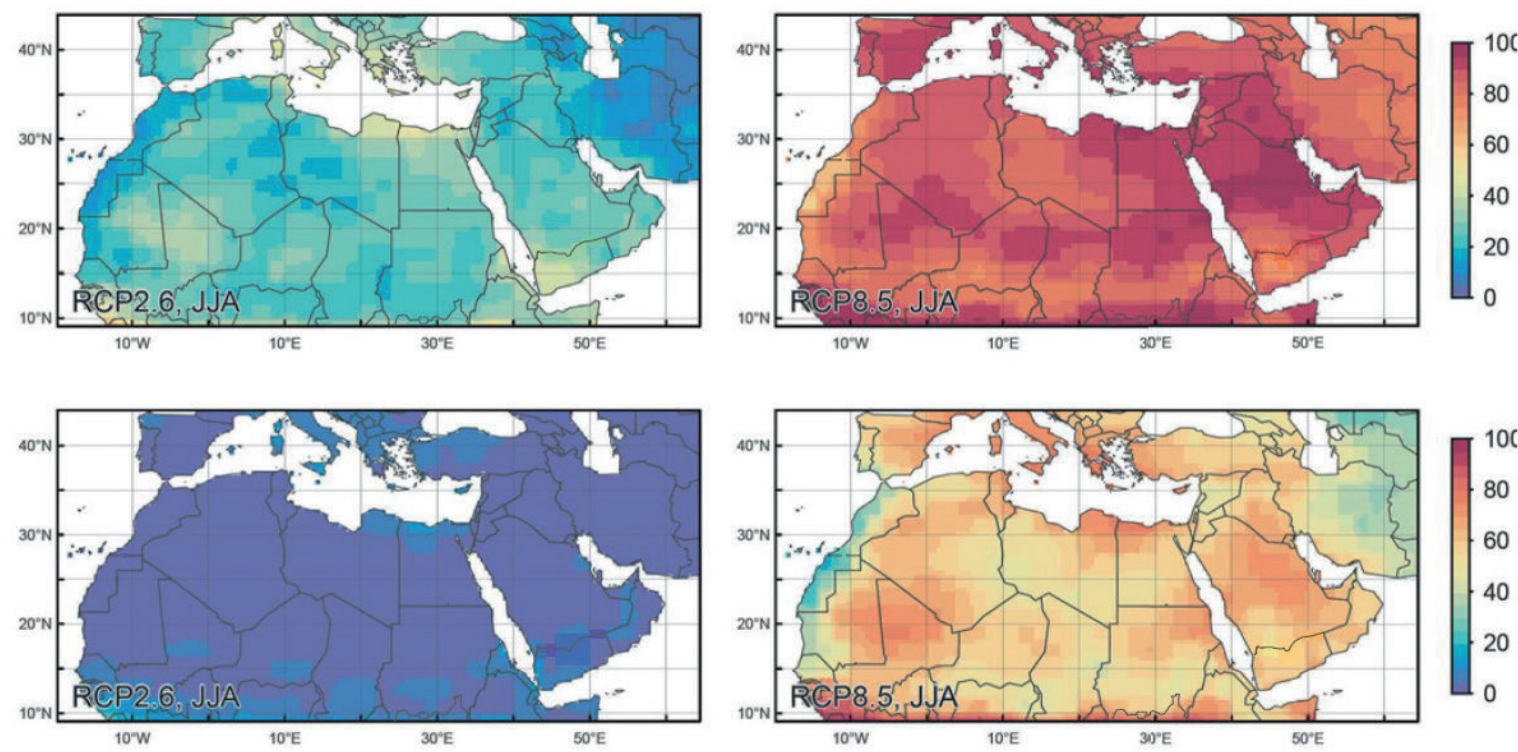

Fig. 9. The percentage of the mean temperature of the summer months (2071-2099)compare with the standard deviation of the reference climate in (1951-1980) based on scenarios RCP2.6 and RCP8.5 according to Word Bank (2014)

the end-of-century projections, special for the RCP8.5 scenario, reference overall agreement among the models. According to IPCC (2013) global mean warming is projected to reach about $2^{\circ} \mathrm{C}$ around 2050 , i.e., a bit less for the RCP4.5 and a bit higher than $2{ }^{\circ} \mathrm{C}$ for the RCP8.5 scenario.

Also, the deep inspection of the (Figure 10) reveals that the $2{ }^{\circ} \mathrm{C}$ approximately synchronizes with the midcentury warming in the Arab countries during winter in the RCP4.5 scenario, albeit that IPCC (2013) relates to preindustrial times while (Figure.10) illustrates to the 1986-
2005 period. It also explains that the quantity of heating during the summer is around twice that through the winter. According to the RCP8.5 scenario, by the end of the century, large parts of the Arab countries in summer are projected to experience a temperature increase in excess of $6{ }^{\circ} \mathrm{C}$ relative to $1986-2005$. Furthermore, the figure shows that climate warming in the Arab countries is stronger than in equatorial Africa, where hydrological feedback through cloud formation limit the increase of temperature at the surface (Lelieveld J. et al. 2016).
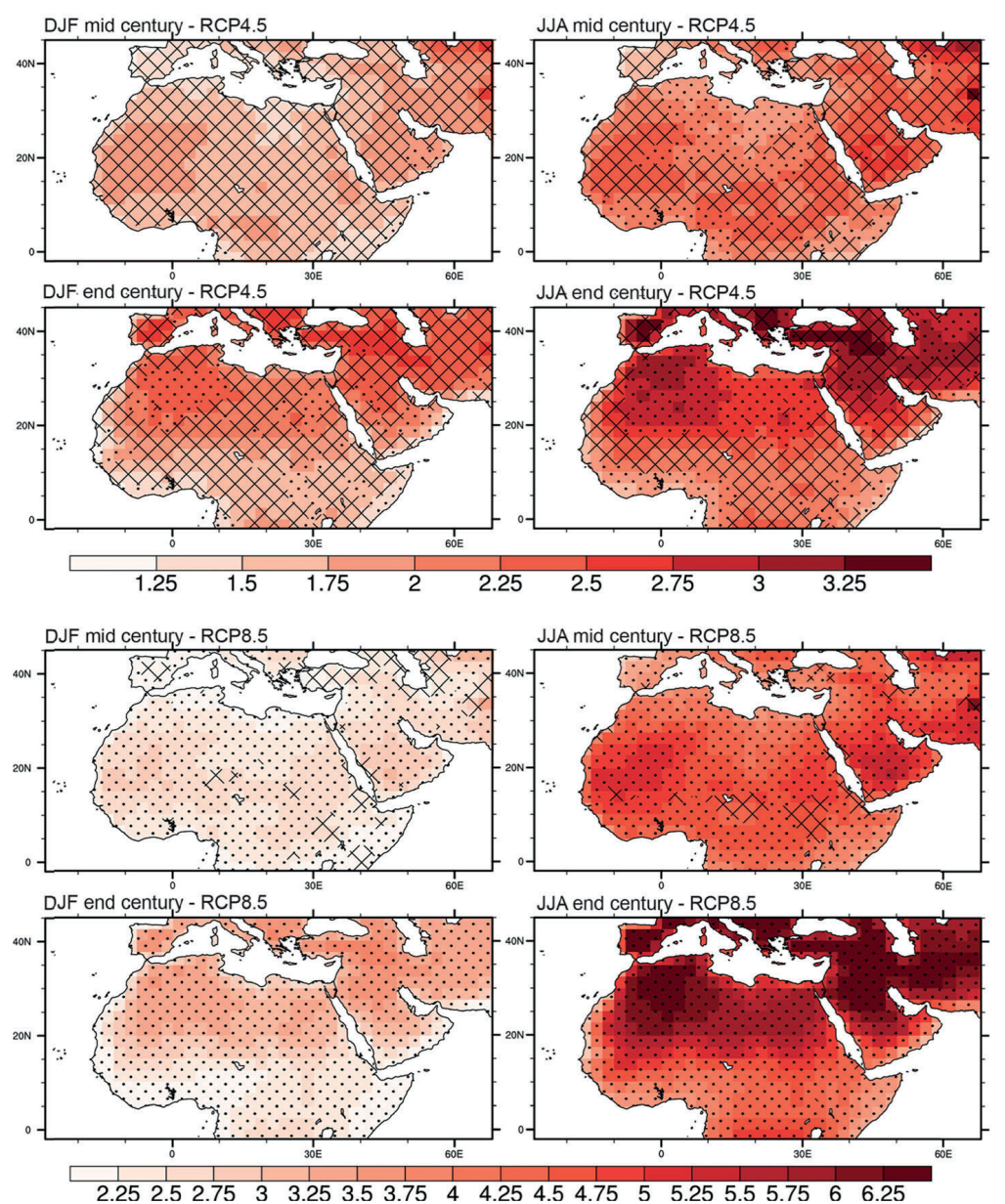

Fig. 10. The robustness of Multi-model means for the change in near-surface temperature in winter and summer months according to the RCP4.5 and RCP8.5 scenarios (After J. Lelieveld et al. 2016) 


\section{Suitability Map for renewable energy exploitation}

The intensive introduction of power generation from renewable energy sources, like solar radiation, wind, and water, as a replacement to traditional power plants depending on ecology-contaminated fossil fuels, requires a punctual and comprehensive database about the current potentials of clean power in the Arab territories. One of the main aims of the research is to provide a definite suitability map of power generation potentials from renewable energy sources in the Arab world. This map could be a guideline and framework for the Arabian policymaker, who are elaborating development plans to exploit natural resources in the Arabian countries.

Producing such a map is based basically on the widerange capabilities of GIS multi-criterion analysis, and feasibly can offer organized priorities of high-to-low promising regions containing clean energy possibilities. We utilized the spatial distribution of the wind and solar radiation (insolation) in each season as a total of eight parameters to GIS model. The data were normalized to a common scale of $0-1$, and then were combined through GIS overlay techniques to produce the suitability map of power generation priorities from physical sources of energy (Figure.11). The Arabian lands are divided into ten zones of suitability according to seasonal possibilities of power generation from wind speed and solar radiation, as quantitatively described in tables $2 \& 3$.

The first suitable zone (Zone 1) indicates areas of the highest renewable energy potentials from both wind speed and solar radiation. Seasonal wind speed in the zone is the largest among the Arabian lands, where it reaches 5.5, 5.8, 8.2 , and $5.7 \mathrm{~m} \mathrm{~s}^{-1}$ in winter, spring, summer, and autumn respectively, in Table 1. It also receives high seasonal insolation of $\left(18.9,24.0,24.3\right.$, and $21.1 \mathrm{MJ} \mathrm{m}^{-2}$ day- $^{-1}$ ) respectively.

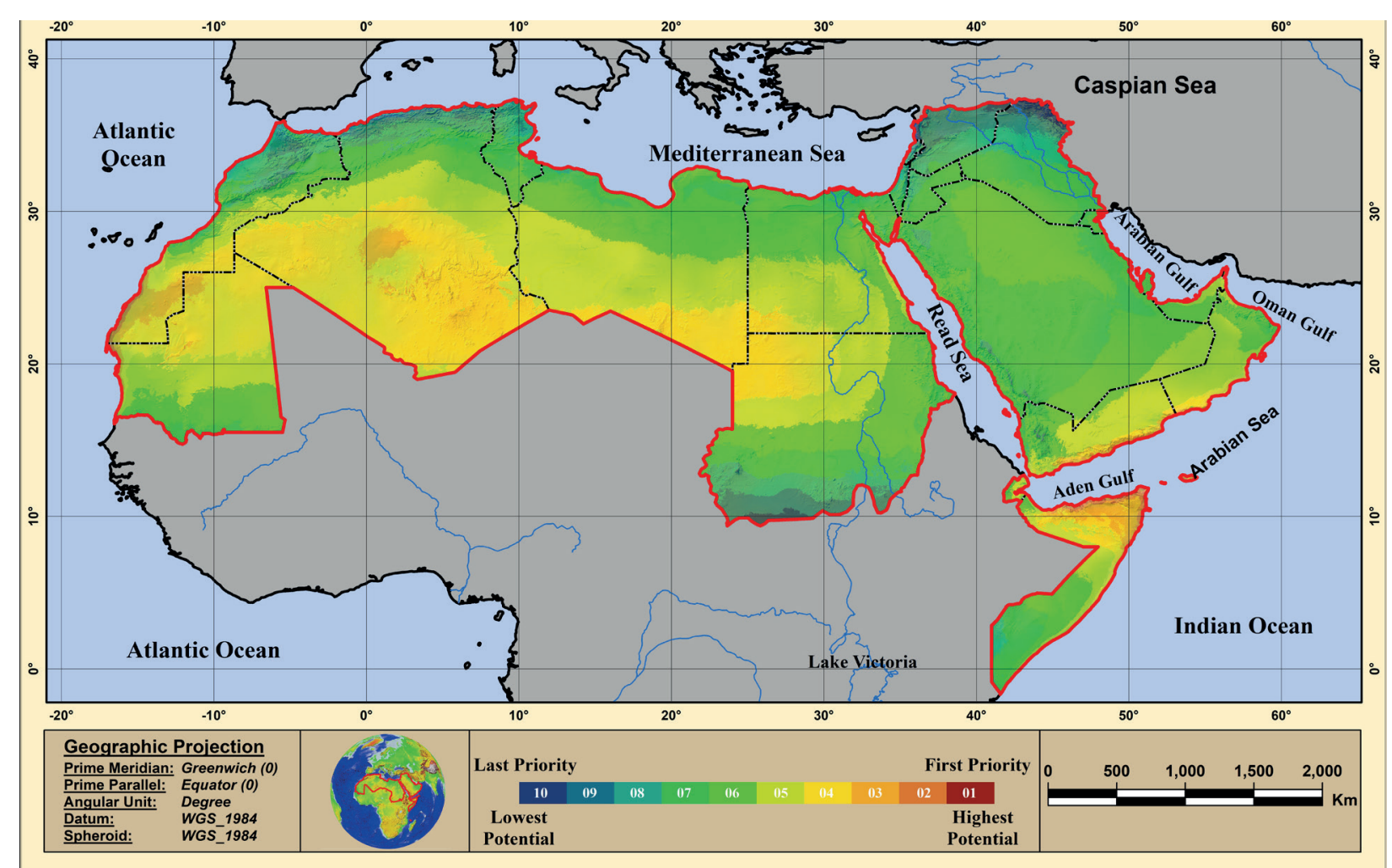

Fig. 11. Suitability map zones of renewable energy potentials and exploitation priorities in the Arab countries

Table 2. Suitability zones characteristics of renewable energy potentials and exploitation priorities in the Arab countries

\begin{tabular}{|c|c|c|c|c|c|c|c|c|c|}
\hline \multirow{2}{*}{$\begin{array}{c}\text { Suitability } \\
\text { Zones }\end{array}$} & Area & \multicolumn{4}{|c|}{ Wind Speed potentials $\left(\mathrm{m} \mathrm{s}^{-1}\right)$} & \multicolumn{3}{|c|}{ Solar Radiation potentials $\left(\mathrm{mj}^{-2} \mathrm{day}^{-1}\right)$} \\
\cline { 3 - 10 } & $\left(1000 \mathrm{Km}^{2}\right)$ & Win. & Spr. & Sum. & Aut. & Win. & Spr. & Sum. & Aut. \\
\hline 1 (Best) & 10.7 & 5.5 & 5.8 & 8.2 & 5.7 & 18.9 & 24.0 & 24.3 & 21.1 \\
\hline 2 & 40.3 & 4.9 & 5.2 & 7.4 & 5.0 & 18.9 & 23.9 & 24.2 & 21.1 \\
\hline 3 & 263.4 & 4.3 & 4.9 & 5.9 & 4.3 & 17.7 & 24.1 & 24.7 & 20.1 \\
\hline 4 & 2418.5 & 3.8 & 4.5 & 4.4 & 3.7 & 17.2 & 24.4 & 25.7 & 19.9 \\
\hline 5 & 2687.0 & 3.3 & 4.0 & 3.9 & 3.3 & 16.9 & 23.6 & 25.0 & 19.7 \\
\hline 6 & 2987.5 & 3.1 & 3.7 & 3.6 & 3.0 & 15.7 & 22.6 & 24.5 & 18.9 \\
\hline 7 & 1962.9 & 2.9 & 3.4 & 3.4 & 2.7 & 15.1 & 21.7 & 23.6 & 18.3 \\
\hline 8 & 710.59 & 2.8 & 3.1 & 3.1 & 2.5 & 13.4 & 20.9 & 23.5 & 16.7 \\
\hline 9 & 372.2 & 2.4 & 2.7 & 2.8 & 2.1 & 12.9 & 20.1 & 22.8 & 16.1 \\
\hline 10 (Worst) & 70.0 & 2.1 & 2.3 & 2.4 & 1.8 & 12.3 & 19.0 & 23.2 & 15.9 \\
\hline
\end{tabular}


So, the zone should be considered as a first priority of exploitation when preparing development plans. However, the first suitable zone has a limited area of $10700 \mathrm{~km}^{2}$ (accounts for $0.1 \%$ of the Arab lands) and extends only in Morocco, Mauritania, Somalia, and Yemen. Suitability map, Fig.1, shows that the spatial distribution of the zone exclusively related to the coastal lands overlooking the Atlantic Ocean in Morocco and Mauritania, and the Indian Ocean in Somalia and Yemen.

The second suitable zone also has a confined space, where it only occupies 0.35\% (approximated to $40300 \mathrm{Km}^{2}$ ). It exists in the same four countries embracing the first zone, besides Oman, and closely related to spatial locations of the first zone. Average wind speeds in the zone are the second largest after the first zone, where they are (4.9, 5.2, 7.4, and $5.0 \mathrm{~m} \mathrm{~s}^{-1}$ ) in winter, spring, summer and autumn respectively. Seasonal averages of incident solar radiation on the area are about 18.9, 23.9, 24.2, and $21.1 \mathrm{MJ} \mathrm{m}^{-2}$ day $^{-1}$ respectively.

\section{Mitigation of the potential climate change hazards}

A 100\% WWS framework in each country will eliminate such hazards in the Arab countries, as they represent the region with the richest renewable energy resources in the world. The range of the 2050 social cost of carbon from recent papers is $\$ 500(282-1,063) /$ metric tonne- $\mathrm{CO}_{2}$ in 2013 dollars (Jacobson et al. 2015a).
The value ranges of climate-change benefits as a result of switching to WWS in the Arab countries, attributed to in-country emissions reduction in 2050 (between 20 and 657 billion dollars) for Sudan and Saudi Arabia, respectively. In addition, the values of climate-change benefits for (Egypt, Iraq, Qatar, and Libya) are (287.01, 155.34, 110.62, and 80.01 billion dollars) respectively based on the middle estimate. While The value ranges of Per-person climatechange benefits in Arab countries as a result of switching to WWS, attributed to emissions reduction in-country in 2050 (\$/person/year) (between 651 and \$43,229/person/Year) for Sudan and Qatar, respectively. In addition, the value of perperson climate-change benefits for (Kuwait, Bahrain, Saudi Arabia, and Oman) are (32,974, 17,083, 16,336, and $\$ 13,865$ / person/Year) respectively based on the middle estimate.

On the other hand, the value ranges of total airpollution-reduction benefits in 2050 (billion 2013-\$) as a result of switching to WWS in the Arab countries, attributed to emissions reduction in country in 2050 (between 6 and 243 billion dollars) for Qatar and Egypt, respectively. In addition, the values of total air-pollution-reduction benefits in 2050 (billion 2013-\$) for (Sudan, Saudi Arabia, Iraq, and Oman) are (236, 102, 103, and 78 billion dollars) respectively based on the middle estimate (Jacobson et al, 2019).

While The value ranges of Per-person air-pollutionreduction benefits in Arab countries as a result of switching

Table 3. The matrix suitability zones of renewable energy potential in the Arab countries

\begin{tabular}{|c|c|c|c|c|c|c|c|c|c|c|c|}
\hline \multirow{2}{*}{ No } & \multirow{2}{*}{ Country } & \multicolumn{10}{|c|}{ Suitability Zones Area (1000 Km²) } \\
\hline & & 1 & 2 & 3 & 4 & 5 & 6 & 7 & 8 & 9 & 10 \\
\hline & Morocco & 3.9 & 11.2 & 71.7 & 126.4 & 91.4 & 87.2 & 91.1 & 124.2 & 24.2 & ----- \\
\hline & Maurita. & 0.4 & 3.4 & 29.3 & 383.6 & 235 & 222.2 & 42.1 & 0.9 & ----- & ---- \\
\hline & Algeria & ----- & ----- & 66.6 & 1188.1 & 414.4 & 152.4 & 109.4 & 111.4 & 63.1 & 0.2 \\
\hline & Tunisia & ----- & ----- & ----- & ----- & 3.7 & 45.6 & 55.3 & 41.8 & 13.4 & ----- \\
\hline & Libya & ----- & ----- & ----- & 231.1 & 662.9 & 473.4 & 89.6 & 3.8 & ----- & ---- \\
\hline & Egypt & ---- & ----- & ----- & 63.6 & 377.7 & 375.9 & 84.9 & 7.3 & ---- & --- \\
\hline & Sudan & ---- & ----- & ---- & 266.7 & 292.3 & 424.9 & 253.6 & 177.5 & 127.4 & 24.2 \\
\hline & Djibouti & ----- & ----- & ----- & 4.4 & 9.9 & 8.3 & 1.7 & ----- & ---- & ---- \\
\hline & Somalia & 6 & 24.8 & 72 & 78.1 & 115.4 & 116.5 & 105 & 22.7 & ---- & ----- \\
\hline & Comoros & ----- & ----- & ----- & ----- & 1.3 & 1.9 & 0.1 & ---- & ----- & ---- \\
\hline & Yemen & 0.4 & 0.8 & 18 & 43.5 & 191.9 & 88.3 & 29.7 & 3.6 & 0.1 & ----- \\
\hline & Oman & ----- & 0.1 & 5.8 & 29.9 & 165.4 & 69.6 & 10.6 & ----- & ----- & ---- \\
\hline & UAE & ----- & ----- & ---- & 3.1 & 23.1 & 42.5 & ----- & ---- & ----- & ----- \\
\hline & Qatar & ----- & ----- & ----- & ----- & 2.9 & 9.1 & 0.6 & ---- & ----- & ---- \\
\hline & Bahrain & ----- & ----- & ----- & ----- & 0.5 & 0.4 & ---- & ---- & ---- & ---- \\
\hline & Kuwait & ----- & ----- & ----- & ----- & 0.5 & 10.6 & 7.7 & ---- & ----- & ---- \\
\hline & Iraq & ----- & ----- & ----- & ----- & ---- & 89.6 & 157.4 & 86.4 & 50.2 & 31.3 \\
\hline & KSA & ----- & ----- & ----- & ----- & 98.7 & 765 & 833.5 & 21.7 & ----- & ---- \\
\hline & Palestine & ----- & ----- & ----- & ----- & ----- & 1.5 & 16.5 & 10.5 & 3.1 & ---- \\
\hline & Jordan & ----- & ----- & ----- & ----- & ----- & 2.57 & 66.1 & 18.7 & 0.7 & ----- \\
\hline & Lebanon & ----- & ----- & ----- & ----- & ---- & ----- & 0.1 & 7.7 & 2.5 & 0.2 \\
\hline & Syria & ----- & ---- & ---- & ---- & ----- & ---- & 7.9 & 72.4 & 87.5 & 14.1 \\
\hline
\end{tabular}


to WWS, attributed to emissions reduction in-country in 2050 (\$/person-year) (between 649 and \$13,306/personYear) for Libya and Oman, respectively. In addition, the value of Per-person air-pollution-reduction benefits for (Bahrain, Kuwait, Iraq, and Egypt) are (3,58, 2,83, 1,82, and $\$ 1.76 /$ person-Year) respectively based on the middle estimate (Jacobson et al, 2019).

Replacing fossil fuels with WWS technologies is expected to generate a total reduction of end-use demand by $60 \%$ relative to a BAU scenario. These projections are based on expected Arab countries' population growth by 32.5\% (between 2017 and 2050). Jacobson et al. (2016, 2017) project that Arab countries' population will grow from 407.5 million in 2016 to 646 million in 2050.

Arab countries' reduction of end-use demand in 2050 is projected to be $51.2 \%$ due to electrification of end uses $6 \%$ due to changes in upstream energy use, and $11.8 \%$ due to additional efficiency measures. Some of the Arab country's efficiency gains due to the electrification of and use in the WWS scenario is projected to be influenced mainly by efficiency in the transportation and industrial sectors (32\% and $43 \%$, respectively).

There are many benefits of using renewable energy sources for Arab countries. At the job creation level, the average job opportunity that will be available about 149,000 . For example, Saudi Arabia will have more than half a million job opportunities. Arab countries will benefit by reducing energy demand by up to 60\%. Moreover, Arab countries will reap the health and financial benefits, especially in health cost savings per year, which will be $6.63 \%$ of each country GDP.

\section{CONCLUSION}

The current research was concluded that most of the Arab countries have done a lot of harsh measures to reduce the negative effects of climate change, and the most important of these measures is to seriously search for renewable energy sources.

The current research adopted Jacobson's et al. (2016) «World plan»,'100\% Renewable Wind, Water, and Sunlight (WWS), and it was validated by assessing the potential renewable energy in Arab countries' WWS, while taking into account the Arab world's unique topography, climate conditions, economic, environmental impacts, and regulation settings.

Based on the estimated 2050 power demand, Arab country's 2050 energy mixes as suggested by Jacobson et al. $(2016,2017)$ are $65.5 \%$ solar, $22.8 \%$ wind, and less than $0.05 \%$ hydro and geothermal. When broken down into specific technologies, the energy mix is as follows: residential rooftop PV system 17.2\%, commercial and governmental rooftop PV 9.1\%, utility-scale PV 32.4\%, CSP plant $14.5 \%$, onshore wind $11.7 \%$, and offshore wind $14.2 \%$. The current research concluded that the appropriate areas that are technically and practically suitable for installing wind farms are mainly in most Arab countries; about 65\% of the area that was found practically suitable for wild winds in the Arab countries particularly in North Africa, in addition to the Empty Quarter Desert in the Kingdom of Saudi Arabia. Thus, Arab countries have enough area that complies with technical limitations for WWS 2050 allpurpose energy demand is generated with onshore wind. The appropriate areas differed technically and practically suitable for installing offshore marine wind turbines mainly vary in the Arab countries. As the lowest percentage reached about $1 \%$ of the area of Iraq, while the percentage reached about $27 \%$ in Lebanon, followed by the State of Oman with a rate of $14.5 \%$, then Egypt and Morocco with a rate of $10.8,10.5$ Respectively.

The practical potential of offshore wind reached an average of $10 \%$ of the total area of the Arab countries, PV on the scale of facilities concentrated solar energy and photovoltaic energy on the residential and commercial surface by at least $37 \%$ is higher than the total plate capacity required for each resource, with less dependence in the form of Great for land and sea winds. This analysis confirms that the Arab countries have enough wind and solar resources to meet their energy demand in 2050 when taking technical constraints into account and when calculating environmental and regulatory restrictions.

The technical capabilities of the Arab countries were confirmed for both wind and solar technologies are greater or like the total capacity of the nameplate required to provide the entire request of Arab countries in 2050 for all purposes of energy.

It has been verified that the practical potential of onshore wind, utility-scale PV and CSP, and residential and commercial PV energy on the commercial and residential surface is greater than or similar to the total panel capacity required to provide the demand of Arab countries for 2050 all-purpose energy according to Jacobson's proposal.

Transforming Arab countries to a 100\% WWS system as suggested by Jacobson et al. (2016) will reduce the enduse demand in 2050 by about 32\%. This difference can be attributed to the conversion of fossil fuel combustions to a more efficient electrified system. All sectors will be electrified as suggested by Jacobson et al. (2016): Short distance ground transportation will be electrified with battery electric vehicles (BEVs) and hydrogen fuel cell vehicles (HFCVs) (hydrogen will be produced by electrolysis from WWS electricity), long-distance ground transportation will use BEVs with fast charging or battery swapping, heavy-duty ground transportation will use BEVHFCV hybrids and ships, aircraft, and long-distance flights will use hydrogen-energy storage.

Despite the current research being dedicated to the analysis of the assessment of climate change impacts on renewable energy sources in the Arab World, the economic, social, and institutional factors must be considered in future researches. 


\section{REFERENCES}

Almazroui M. (2012). Dynamical downscaling of rainfall and temperature over the Arabian Peninsula using RegCM4. Clim. Res. 52, 49-62, DOI: $10.3354 / \mathrm{cr} 01073$.

Almazroui M. (2016). RegCM4 in climate simulation over CORDEX-MENA/Arab domain: selection of suitable domain, convection and land-surface schemes. Int. J. Climatol, 36, 236-251, DOI: 10.1002/joc.4340 [Accessed January 2019].

Almazroui M., Islam M.N., Al-Khalaf A.K., Saeed F. (2015). Best convective parametrization scheme within RegCM4 to downscale CMIP5 multi-model data for the CORDEX-MENA/Arab domain. Theor. Appl. Climatol, 124, 807-823.

Almazroui M., Islam M.N., Alkhalaf A.K., Saeed F., Dambul R., Rahman M.A. (2016). Simulation of temperature and precipitation climatology for the CORDEX-MENA/ Arab domain using RegCM4. Arab. J. Geosci. 9 (1), 1-13.

Andrade C., Corte Real J. (2014). Spatial distribution of climate change indices in the Iberian Peninsula. ICNAAM-2014. AIP Conf Proc 1648: 1

Arab Union of Electricity (2016b). Statistical Bulletin 2016. Available at https://www.irena.org/-/media/Files/IRENA/Agency/ Publication/2016/IRENA_Arab_Region_Overview_2016.pdf [accessed March 2019].

Arab Monetary Fund (2019). Database available at https:// www.amf.org.ae/en/arabic_economic_database [accessed January 2020].

Arnold T. (2019). Saudi's PIF invests more than $\$ 1$ billion in electric carmaker Lucid Motors. Reuters, 17 September 2018. Available at https://www.reuters.com/article/us-saudiinvestment- auto/saudis-pif-invests-more-than-1-billion-inlucid- motors-idUSKCN1LX1IG.

Baltas E. (2007). blpatial distribution of climatic indices in northern Greece. Meteorol Appl 14: 69-78

Beck Thorsten. (2011). Finance and Oil: Is Therea Resource Curse in Financial Development?, In Beyond the Curse: Policies to Harness the Power of Natural Resources, edited by Rabah. Arezki, Thorvaldur Gylfason and Amadou Sy. Washington, DC: International Monetary Fund.

Centre for Environment and Development for the Arab Region and Europe (2016). Fuel Economy Policies \& Labeling for New Cars:Improving Fuel Efficiency and CO2 Emissions in Egypt. Available at http://pharos.cedare.org/wp-content/ uploads/2017/01/HandoutFuel-Economy-for-Cars_Policy_Brief_EGYPT-GFEl.pdf

Collins W.D., Ramaswamy V., Schwarzkopf M.D., Sun Y., Portmann R.W., Fu Q., Casanova S.E.B., Dufresne J.-L., Fillmore D.W., Forster P.M.D., Galin V.Y., Gohar L.K., Ingram W.J., Kratz D.P., Lefebvre M.-P. et al. (2006). Radiative forcing by well-mixed greenhouse gases: Estimates from climate models in the Intergovernmental Panel on Climate Change (IPCC) Fourth Assessment Report (AR4). J. Geophys. Res., 111, D14317, DOI:10.1029/2005JD006713.

Coumou D., Robinson A. and Rahmstorf S. (2013). Global increase in record-breaking monthly-mean temperatures Clim. Change, 118, 771-82.

Croitoru A., Piticar A., Imbroane A.M., Burada D.C. (2013). Spatio temporal distribution of aridity indices based on temperature and precipitation in the extra-Carpathian regions of Romania. Theor Appl Climatol 112: 597-607.

Deng L., McCabe M.F., Stenchikov G., Evans J.P., Kucera P.A. (2015). Simulation of flash-flood-producing storm events in Saudi Arabia using the weather research and forecasting model. J Hydrometeorol, 16, 615-630.

Donat M.G. et al. (2014). Changes in extreme temperature and precipitation in the Arab region: long-term trends and variability related to ENSO and NAO. Int J Climatol, 34, 581-592.

El Kenawy A., Lopez-Moreno J., Vicente-Serrano S., MekldM (2009). Temperature trends in Libya over the second half of the 20th century. Theor Appl Climatol, 98, 1-8.

El Kenawy A., Lopez-Moreno J., Vicente-Serrano S., Abdelal M. (2010). Temperature variability along the Mediterranean and its links to large-scale atmospheric circulation (1957-2006), Bull Egypt Geog Soc, 83, 121-140.

El Kenawy A., McCabe M.F., Stenchikov G., Raj J. (2014). Multi-decadal classification of synoptic weather types, observed trends and links to rainfall characteristics over Saudi Arabia. Front Environ Sci, 2, 37.

Grell G.A., Dudhia J., \& Stauffer D.R. (1994). A Description of the Fifth Generation Penn State/NCAR Mesoscale Model (MM5). Boulder: National Center for Atmospheric Research.

Giorgi F., Lionello P. (2008). Climate change projections for the Mediterranean region. Glob. Planet. Chang. 63(2), 90-104.

Giorgi F., Jones C., Asrar G.R. (2009). Addressing climate information needs at the regional level: the CORDEX framework. In: World Meteorological Organization (WMO) Bulletin, 58(3), 175.

International Renewable Energy Agency (2019a). Renewable Energy Market Analysis: GCC (2019). Abu Dhabi. https://www.irena.org/ publications/2019/Jan/Renewable-Energy-Market- Analysis-GCC-2019 [Accessed January 2020].

International Renewable Energy Agency (2019b). Renewable Capacity Statistics 2019. Abu Dhabi. Available at https://www.irena.org/ publications/2019/Mar/Renewable-Capacity- Statistics-2019 [Accessed January 2020]

IPCC (2013a). In: Stocker T.F., Qin D., Plattner G.-K., Tignor M., Allen S.K., Boschung J., Nauels A., Xia Y., Bex V., Midgley P.M. (Eds.), Climate Change 2013: The Physical Science Basis. Contribution of Working Group I to the Fifth Assessment Report of the Intergovernmental Panel on Climate Change. Cambridge University Press, Cambridge. https://www.ipcc.ch/report/ar5/wg1/ [Accessed March 2019].

IPCC (2013b). Annex I: atlas of global and regional climate projections. In: van Oldenborgh, G.J., Collins, M., Arblaster, J., Christensen, J.H., Marotzke, J., Power, S.B., Rummukainen, M., Zhou, T. (Eds.), Climate Change 2013: The Physical Science Basis. Contribution of Working Group I to the Fifth Assessment Report of the Intergovernmental Panel on Climate Change. Cambridge University Press, Cambridge, United Kingdom and New York, NY, USA (Stocker TF, Qin D, Plattner GK). https://www.ipcc.ch/site/assets/uploads/2018/02/WG1AR5_Annexl_FINAL-1.pdf [Accessed January 2019].

IPCC (2018). An IPCC Special Report on the impacts of global warming of $1.5^{\circ} \mathrm{C}$ above pre-industrial levels and related global greenhouse gas emission pathways, in the context of strengthening the global response to the threat of climate change, sustainable development, and efforts to eradicate poverty, IPCC, Switzerland, 2018.https://www.ipcc.ch/site/assets/uploads/sites/2/2019/06/SR15_Full_Report_High_Res. pdf [Accessed January 2019].

Kottek M., Grieser J., BeckC., RudolfB. and Rubel F. (2006)World Map of the Köppen-Geiger climate classification updated, Meteorologische Zeitschrift, 15(3), 259-263.

Laprise R., Hernandez-Diaz L., Tete K., et al. (2013). Climate projections over CORDEX Africa domain using the fifth-generation Canadian regional climate model (CRCM5). Clim. Dyn. 41, 3219e3246, DOI: 10.1007/s00382-012-1651-2.

Lelieveld J., Hadjinicolaou P., Kostopoulou E., et al. (2012). Climate change and impacts in the eastern mediterranean and the Middle East. Climatic Change 114, 667e687, DOI: 10.1007/s10584-012-0418-4. 
Lelieveld J., Proestos Y., Hadjinicolaou P., et al. (2016). Strongly increasing heat extremes in the Middle East and North Africa (MENA) in the 21 st century. Climatic Change, 137, 245e260, DOI: 10.1007/s10584-016-1665-6.

Mitchell T.D., Jones P.D. (2005). An improved method of constructing a database of monthly climate observations and associated highresolution grids. Int. J. Climatol. 25(6), 693e712, DOI: 10.1002/joc.1181.

Nazemosadat M.J., Cordery I. (2000). On the relationships between ENSO and autumn rainfall in Iran. Int J Climatol, 20, 47-61.

Önol B and Semazzi FHM. (2009). Regionalization of climate change simulations over the Eastern Mediterranean. J Clim, 22, $1944-1961$.

Önol B., Bozkurt D., Turuncoglu U.U., Sen O.L., Dalfes H.N. (2014). Evaluation of the twenty-first century RCM simulations driven by multiple GCMs over the Eastern Mediterranean-Black Sea region. Clim Dyn, 42, 1949-1965.

Pasicko, Robert et al. (2012). Assessment of climate change impacts on energy generation from renewable sources in Croatia, Renewable Energy 46 (2012) 224e231 (The rest of the authors' names).

Seneviratne S.I., Nicholls N., Easterling D., Goodess C.M., Kanae S., Kossin J., Luo Y., Marengo J., McInnes K., Rahimi M., Reichstein M., Sorteberg A., Vera C., Zhang X. (2016). Changes in climate extremes and their impacts on the natural physical environment. In: Field CB, Barros V, Stocker TF, Qin D, Dokken DJ, Ebi KL, Mastrandrea MD, Mach KJ, Plattner G-K, Midgley PM, Allen SK, Tignor M, Midgley PM (eds) Managing the risks of extreme events and disasters to advance climate change adaptation. A special report of working groups I and II of the intergovernmental panel on climate change (IPCC), Cambridge: Cambridge University Press, 109-230.

Sillmann J., Kharin V.V., Zwiers F.W., Zhang X., and Bronaugh D. (2013). Climate extreme indices in the CMIP5 multi-model ensemble. Part 2: Future projections, J. Geophys. Res., (pp. 109-230), DOl: 10.1002/jgrd.50188.

Somot S., Sevault F., Déqué M., Crépon M. (2008). 21st century climate change scenario for the Mediterranean using a coupled atmosphere-ocean regional climate model. Glob. Planet. Chang, 63(2), 112-126.

UNEP (2015). Climate Change in the Arab Region. Regional Coordination Mechanism (RCM) Issues Brief for the Arab Sustainable Development Report. Available at http://css.escwa.org.lb/SDPD/3572/Goal13.pdf [Accessed March 2019].

UN ESCWA (2015e). Survey of Economic and Social Development in the Arab Region 2014-2015. Available at https://www.unescwa. org/publications/survey-economic-and-social development- arab-region-2014-2015 [Accessed March 2019].

UN ESCWA (2016d). Arab Governance Report II: Governance and Institutional Transformations in Conflict-affected Arab Countries. Available at https://www.unescwa.org/publications/arabgovernance- Report-2016. [Accessed March 2020].

World Bank (2014). Turn Down the Heat: Confronting the New Climate Normal. Washington, DC: World Bank. License: Creative Commons Attribution-Non Commercial-No Derivatives 3.0 IGO (CC BY-NC-ND 3.0 IGO). http://documents1.worldbank.org/curated/ en/317301468242098870/pdf/927040v20WP0000ullOReport000English.pdf [Accessed January 2020].

World Bank (2016a). Delivering Energy Efficiency in the Middle East and North Africa. International Bank for Reconstruction and Development, Washington DC, USA. Available at https://openknowledge.worldbank.org/ bitstream/handle/10986/25295/109023WPP148222- PUBLIC-DeliveringEEinMENAMayEN. pdf?sequence=1\&isAllowed=y [A ccessed April 2020].

World Bank (2017). Health, Nutrition and Population Statistics Database. Available at http://data.worldbank.org/data-catalog/ healthnutrition- and-population-statistics [Accessed March 2020].

Zittis G., Hadjinicolaou P. (2017). The effect of radiation parameterization schemes on surface temperature in regional climate simulations over the MENA-CORDEX domain. Int. J. Climatol, 37(10), 3847-3862. 